\title{
Constitutional Governance in India and China and Its Impact on National Innovation
}

\author{
Wenjuan Zhang
}

\begin{abstract}
India and China have attracted research interest due to their potential to catch up to developed nations. The framework of the National Innovation System (NIS) is a popular theory to explain the role of the state in supporting knowledge creation and learning capacity for the catching-up stage. Various comparative studies on sectoral innovation or geography of innovation in India and China have been conducted, mainly by economists. This chapter tries to bring the non-quantified factor-constitutional governance into the discussion from three aspects of the political philosophy for achieving social revolution and social justice, power distribution from three dimensions of vertical, horizontal, and state versus citizen, which have not been favored by economists, due to their lack of rigorousness. At the end, the chapter applies the factors to the analysis of their influence on the economic development path and on the innovation strategy in India and China.
\end{abstract}

\section{Keywords}

India $\cdot$ China $\cdot$ Constitutional governance $\cdot$ National innovation $\cdot$ Comparison

\section{Introduction}

The attention to national innovation capacity was first captured by economists. The concept of national innovation capacity is usually traced back to Joseph Schumpeter in the early twentieth century. However, the National Innovation System (NIS) as a

\section{W. Zhang $(\bowtie)$}

Jindal Global Law School and Center for India-China Studies, O.P. Jindal Global University, Sonipat, Haryana, India

e-mail:wzhang@jgu.edu.in 
separate concept was raised in the 1980s and further developed by economists, under the influence of the social psychological pragmatist school of Chicago and the ideas of George Mead and John Dewey. ${ }^{1}$ The pragmatist version of economic development that "the most important resource in the economy is knowledge and the most important process is learning"2 is very close to the pragmatist theory in spirit. Today NIS is a very popular concept among academia and policymakers.

India and China are two developing countries which have attracted strong research interest in their innovation capacity due to their rapid economic growth and large domestic commercial markets. Several research efforts have been made under the NIS framework, either by comparing India to China on the general topic of innovation, such as "innovation capacity and economic development"3 and "transition from production to innovation,"4 or by conducting the comparison on more specific innovation such as sectoral innovation in the telecom industry ${ }^{5}$ or on "geography of innovation." 6

Bengt-Ake Lundvall, one of the founding scholars of the NIS, reminds us that the focus on the "wider setting" including "the shared value in society and the power structure" may be especially important for the analysis of NIS in developing or less developed countries. ${ }^{7}$ However, in the current comparative studies on innovation in India and China, economists prefer the quantitative analysis due to its rigorousness. Attention to the comparative studies of innovation in India and China has been given to input factors such as R\&D input and higher education or structural conditions such as GDP per capita, transportation infrastructure, agglomeration, and migration flows. Even if some research has mentioned the "social filter" factors, such as "social and business networks," "social stratification," and "levels of modernity," it has still focused on the quantitative factors such as education rate,

\footnotetext{
${ }^{1}$ Bengt-Åke Lundvall, National Innovation Systems-Analytical Concept and Development Tool, second version of the paper presented at the DRUID conference in Copenhagen, June 28-29, 2005, available at https://www.researchgate.net/publication/24081600_National_Innovation_SystemsAnalytical_Concept_and_Development_Tool. Footnote 7, p. 11. This school focuses on interactive, reflective, and dialectical learning and problem-solving with recent influential publications of this school such as Pragmatist Democracy by Christopher K. Ansell, Oxford University Press, 2011.

${ }^{2}$ Lundvall, supra note 1, p. 11.

${ }^{3}$ Peilei Fan, Innovation Capacity and Economic Development: China and India, Research Paper, UNU-WIDER, United Nations University (UNU), No. 2008/31, ISBN 978-92-9230-077-7.

${ }^{4}$ Tilman Altenburg, Hubert Schmitz, and Andreas Stamm, Breakthrough? China's and India's Transition from Production to Innovation, 36 World Development, No. 2, pp. 325-344, 2008.

${ }^{5}$ Sunil Mani, The Dragon v. the Elephant, Comparative Analysis of Innovation Capacity in the Telecom Industry of China and India, 40 Economic and Political Weekly, No. 39, Sep. 24-30, 2005, pp. 4271-4283.

${ }^{6}$ Riccardo Crescenzi, Andres Rodriguez-Pose, and Michael Storper, The Territorial Dynamics of Innovation in China and India, 12 Journal of Economic Geography, 5, 2012, pp. 1055-1085.

${ }^{7}$ Lundvall, supra note 1, p. 31.
} 
employment rate, or rural-urban migration rate. ${ }^{8}$ While there are very few comparative studies on governance and development in India and China ${ }^{9}$ or on "the role of sociopolitical factors in inclusive growth" 10 in India and China, there has been little or even no attention to developing the discourse around innovation.

When asked to reflect on the relationship between "the shared value in society and the power structure" and national innovation, two questions appear to be critical: (1) To what extent can constitutional governance be considered in developing the NIS conceptual framework and for comparison of cross-national NIS? (2) Could some qualitative description of India and China, which have so many similarities but also possess critical differences in terms of different constitutional governance for modernization, be meaningful in the conceptual framework of NIS?

This chapter considers the "wider setting," especially the "shared value" and "power structure" mentioned by Lundvall, is highly relevant to the concept of NIS. However, this is far from the methodology and factors favored by economists. It picks up on factors economists disregard due to the difficulty in quantifying them, such as the political philosophy of constitutional governance for social mobility and social justice, the government accountability and innovation policy through horizontal and vertical power structure, and also the confidence in rights protection through the mechanism of constitutional enforcement. My goal in this chapter is to foster further academic interest to enrich the literature in the field of NIS and governance, although it is very limited, even superficial, compared to the big research topics raised in the above two questions.

\section{Brief Introduction to the National Innovation System}

Before moving to the discussion of the "shared value" and "power structure" emphasized by Lundvall for the analysis of innovation in developing countries, we begin with a brief introduction to the concept of NIS. Inspired by Schumpeter, scholars such as Christopher Freeman have further developed the theory of technological innovation. ${ }^{11}$ Robert Solow has also made substantial efforts to quantify the impact of technology on economic growth. ${ }^{12}$ In the 1980s, the concept of NIS was

\footnotetext{
${ }^{8}$ Crescenzi et al., supra note 6, pp. 14-15.

${ }^{9}$ Pranab Bardhan, Indian and China: Governance Issues and Development, 68 The Journal of Asian Studies, No. 2, May 2009.

${ }^{10} \mathrm{C}$ H Hanumantha Rao, India and China: A Comparison of the Role of Sociopolitical Factors in Inclusive Growth, 46 Economic and Political Weekly, No. 16 (April 16-22, 2011), pp. 24-28.

${ }^{11}$ Jan Fagerberg, Morten Fosaas, Martin Bell, and Ben Martin, Chris Freeman's Contribution to Innovation Studies, EXPLORE Workshop, 2010, http://www.janfagerberg.org/wp-content/ uploads/2013/08/Chris-Freeman\%E2\%80\%99s-contribution-to-innovation-studies-1.pdf, pp. $4-5$.

${ }^{12}$ Nathan Rosenberg, Innovation and Economic Development, https://www.oecd.org/cfe/tourism/34267902.pdf, OECD 2004, p. 1.
} 
developed as a separate concept, especially in research about the role of the state in the catching-up process which challenged the Washington Consensus. ${ }^{13}$ Special credit was given to Christopher Freeman's book Technology policy and economic performance: lessons from Japan in 1987 for the promotion of NIS. ${ }^{14}$

The early attention to NIS "refers to the fact that historical and local context affects where the limits of innovation systems are set." 15 Later, scholars such as Bengt-Åke Lundvall, Nelson, R. R, and Charles Edquist further developed the concept of NIS. ${ }^{16}$ Thus, research inquiry was extended to focus areas such as "social systems of innovation," "sectoral system of innovation," "national business system," etc. in the last decade. ${ }^{17}$

Compared to previous theories, NIS's three critical contributions have been emphasized. First, it moves the emphasis for achieving international competitiveness from traditional cost factors and incentives such as cheap labor, devaluation, and tax cuts to innovation.

Second, innovation is defined broadly, including both radical and incremental innovation, even including the diffusion, absorption, and use of innovation. ${ }^{18}$ Some have divided it into two types, "science-based" ("promoting R\&D, utilizing and creating access to explicit codified knowledge") or "experience-based" ("learning by doing, using and interacting"). ${ }^{19}$ Some others have placed it into the category of "production capability" ("adapting existing knowledge and minor innovation") or "innovation capability" (new technology for hardware or new soft knowledge for organizing firms). ${ }^{20}$

Third, it brings state back and develops analysis around "how different countries differ in terms of institutional setups supporting innovation and learning," 21 instead of just focusing on the firm-level innovation. It also focuses on the interaction between users and producers, the interaction among firms, and the wide institutional and social arrangements for innovation.

In summary, "the innovative capacity depends on the density and quality of relationships among enterprises and the relationship between enterprises and support institutions." 22 Or we can conclude that "innovation is regarded as socially and spatially embedded interactive learning process that cannot be understood independently of its region-specific institutional and cultural context." ${ }^{23}$

\footnotetext{
${ }^{13}$ Lundvall, supra note 1, p. 3. (Washington Consensus is a phrase referring to economic policies recommended by international institutes such as the Institute for International Economics, International Monetary Fund, World Bank, etc. in the 1980s. Some also frame the Washington Consensus as market fundamentalism or neoliberalism.).

${ }^{14}$ Ibid.

${ }^{15}$ Ibid.

${ }^{16} \mathrm{Ibid}$.

${ }^{17}$ Lundvall, supra note 1, p. 6.

${ }^{18}$ Lundvall, supra note 1, p. 12.

${ }^{19}$ Lundvall, supra note 1, p. 9.

${ }^{20}$ Altenburg et al., supra note 4, p. 327.

${ }^{21}$ Lundvall, supra note 1, p. 8.

${ }^{22}$ Altenburg et al., supra note 4, p. 327.

${ }^{23}$ Altenburg et al., supra note 4, p. 328.
} 
There are also some critical assessments of the NIS concept. For example, it has been pointed out by many scholars that the understanding of the dynamics of innovation systems is still weak, ${ }^{24}$ such as "how the structures of interaction develop and change over time." 25 Some others suggest that understanding of the dynamics of interactive learning "calls for other disciplines than economics." ${ }^{26}$ Another critical comment is on its "scientification approach," with too much focus on rigorousness of the research. ${ }^{27}$ There have also been suggestions to move the research from an aggregate national level to more specific ones such as regional and sectoral levels, which have been taken by many economists.

This chapter tries to bring the perspective of constitutional law into the NIS research. Constitutional governance is at the apex of power distribution, which is the foundation for understanding the power structure and institutional support. However, it will be limited to explaining the dynamics of interaction between business units and institutional support in a nuanced way.

\section{Different Political Philosophy for Social Revolution and Social Justice}

Political philosophy sets the foundation and tone for the design and function of constitutional governance. India and China are two countries that believe socialism is the right path for the modernization of underdeveloped and post-colonized nations with large poor and illiterate populations. Both have put socialism into the preamble of their constitution, but follow different schools of socialism, Fabianism for India and Marxism and Leninism for China. ${ }^{28}$ The different versions of socialism substantially influence their ways of pursuing social revolution and social justice, which are believed to have different impacts on the social foundation of national innovation capacity in each context.

\subsection{Social Revolution: Violent Revolution vs. Democratic Governance}

Both India and China are ancient civilizations with long histories. Interestingly, their long cultural traditions carry both nutrients and burdens for their modernization. Cultural inequality is one of the critical barriers for social equality and social mobility. Social mobility is further critical for industrial entrepreneurship, since

\footnotetext{
${ }^{24}$ Ibid.

${ }^{25}$ Ibid.

${ }^{26}$ Lundvall, supra note 1, p. 5. (In arguing for this point, he referred to Reijo Miettinen's comment on the NIS in a publication in 2002.)

${ }^{27}$ Ibid.

${ }^{28}$ K. V. Viswanathaiah, Jawaharlal Nehru's Concept of Democratic Socialism, 26 The Indian Journal of Political Science, No. 4, October-December 1965, pp. 91-99.
} 
"[industrial] entrepreneurship can develop only in a society in which cultural norms permit variability in the choice of paths of life." ${ }^{29}$

Both India and China have made efforts for social revolution in the new nationbuilding but in different ways. In the struggle for independence, India followed Gandhi's non-violent civil disobedience, while China followed Mao Zedong's revolutionary violence with "ideological commitment to the fundamental alteration of the class relationship," especially in rural areas. ${ }^{30}$ This commitment to fundamental alteration of the class relationship was continued in the first three decades of the People's Republic of China (PRC) and was even strengthened during the Cultural Revolution under the leadership of Mao. Unlike the leadership of China, Gandhi, Nehru, and other founding leaders of India employed non-violence for social revolution, while they disagreed on industrialization for development. ${ }^{31}$ Further, members of the Constitutional Assembly believe that direct election is the pillar for social revolution. ${ }^{32}$

The Assembly has adopted the principle of adult franchise (said) with an abundant faith in the common man and the ultimate success of democratic rule, and the full belief that the introduction of democratic government on the basis of adult suffrage will bring enlightenment and promote the well-being, the standard of life, the comfort, and the decent living of the common man..$^{33}$

Nobel laureate Amartya Sen, Indian-born economist and philosopher, also argued in his book Development as Freedom that social opportunities such as access to primary education and basic health care are not only "important for the conduct of private life" but also important for "effective participation in economic and political life." ${ }^{34}$ China has improved life expectancy and literacy as well as reduced infant mortality within a short period. ${ }^{35}$ Despite its poorer status compared to India, from 1949 to1953 China was able to raise the life expectancy to 40.3, while the life expectancy in India remained 32.1 in 1951, almost no change from that of $1947 .{ }^{36}$ In the mid-1970s, life expectancy in China reached 63.6 for men and 66.3 for women, compared to an average of only 49.4 in India despite the great political

\footnotetext{
${ }^{29}$ Phiroze B. Medhora, Entrepreneurship in India, 80 Political Science Quarterly, No. 4 Dec. 1965, p. 564. (He quoted from the research of Bert Hoselitz.)

${ }^{30}$ Jason Unruhe, Contrast India \& China: What a Difference Revolution Makes!, July 20, 2010, Jason Unruhe. Com, https://maoistrebelnews.com/2010/07/20/contrast-india-china-what-adifference-revolution-makes/

${ }^{31}$ Kazuya Ishii, The Socioeconomic Thoughts of Mahatma Gandhi: As An Origin of Alternative Development, Review of Social Economy, Vol. LIX, No. 3, September 2001, p. 301.

${ }^{32}$ Granville Austin, The Indian Constitution: Cornerstone of a Nation, Oxford University Press, 2009 , p. 58.

${ }^{33}$ Ibid.

${ }^{34}$ Amartya Sen, Development as Freedom, Oxford University Press, 1999, p. 39.

${ }^{35}$ Unruhe, supra note 30.

${ }^{36}$ Ibid.
} 
turmoil and many natural disasters in China. ${ }^{37}$ By 1980-1981, China's infant mortality rate fell to 56 per 1000 live births, while the Indian level remained at a high $122 .{ }^{38}$ There is also a big gap in improving literacy in India and China. For example, in 1964, Chinese illiteracy dropped to $52.4 \%{ }^{39}$ while it was $63.77 \%$ in 1981 in India. The gap is still expanding. By the end of 2014, India's adult illiteracy rate was $29.5 \%,{ }^{40}$ while China's has dropped to $4.1 \% .{ }^{41}$ Although many factors contributed to the rise of China, some scholars believe that "it was the 'head start' provided by the socialist revolution - in better health, education, infrastructure development and social egalitarianism - that laid the basis for this later advance." 42 Sen also argued that economic liberalization in India has not achieved an outcome similar to China and that this is due to lack of social preparedness, evidenced by the fact that half of its adult population was illiterate in $1991 .^{43}$

The Chinese revolution was not achieved without costs, such as civil war and the death of millions in famine, even after the establishment of the PRC. The social disruption and violence caused by the Cultural Revolution dragged Chinese society into a devastating trauma. ${ }^{44}$ Starting in 1978 , the political focus has shifted to economic development. Benefiting from social liberation and decentralized power, within a short period of time, China became the world's factory, transforming China "from one of the most egalitarian countries in the world, into among the most polarized," with new stratification, a dangerously high Gini index, a high suicide rate among farmers, and a host of social conflicts and protests. ${ }^{45}$

Although India has lagged in most key economic and demographic indicators compared to China, the gradual social change has saved India from dramatic political turbulence and from wild economic and social transformation as well. Meanwhile, India has made evident progress toward social equality among classes and castes through its constitutional arrangements. Untouchability was abolished by the Constitution and is not visible in daily life. Through seats reservation for education, government jobs, and elected positions as an affirmative action in the Constitution, the status of many people from low castes and underprivileged tribes

\footnotetext{
${ }^{37}$ Ibid.

${ }^{38}$ Ibid.

${ }^{39}$ Shanghai Institute of Education Studies, Contextualized Analysis on Chinese Human Resources (in Chinese), Shanghai Institute of Education Studies, June 12, 2010, http://www.cnsaes.org/ homepage/Upfile/2010612/2010061205505377.pdf. (The age basis for adult illiteracy here was 13, which was lifted to 15 after 2008.)

${ }^{40}$ Department of School Education and Literacy, Ministry of Human Resources Development (MHRD), Education Statistics At A Glance, 2016, http://mhrd.gov.in/sites/upload_files/mhrd/files/ statistics/ESG2016_0.pdf

${ }^{41}$ Data from the UNDP China Office, p. A1, http://www.cn.undp.org/content/china/zh/home/ mdgoverview/overview/mdg2.html

${ }^{42}$ Unruhe, supra note 30.

${ }^{43}$ Sen, supra note 34 , p. 42 .

${ }^{44}$ Unruhe, supra note 30.

${ }^{45}$ Ibid.
} 
was raised. Low caste has even become a selling point for getting votes such as in elections for Lok Sabha (meaning the "Council of States") ${ }^{46}$ and president. ${ }^{47}$

However, concerns about social inequality in India still exist. For example, one scholar argues that "it did not put an end to the institutional aspects of class exploitation and caste oppression." ${ }^{48}$ Another scholar even asserted that the Nehruvianism version of the emancipation project "was simply rendering oppression invisible." 49 The caste politics in more than the last two decades "has largely confined itself to the ambition of gaining access to power rather than any substantial agenda of social transformation." 50 It has even become a big puzzle of Indian democracy as to "why the poor, so assertive when election time comes, often do not punish politicians who are ineffective at resolving the endemic problems of poverty, disease and illiteracy." ${ }^{51}$

\subsection{Pursuing Social Justice: Transcendental Institutionalism vs. Realization-Focused Comparison}

Amartya Sen in his thought-provoking book The Idea of Justice divides "the two basic and divergent lines of reasoning about justice among leading philosophers" 52 into "transcendental institutionalism" which "concentrated on identifying just institutional arrangements for a society" 53 and "realization-focused comparison," which "took a variety of comparative approaches that were concerned with social realizations (resulting from actual institutions, actual behaviors and other influences)." ${ }^{54}$ In terms of institutional arrangement, the reasoning of the Communist Party of China (CPC) is more from the perspective of comparison and realization under the theory developed by Amartya Sen in his thought-provoking book The Idea of Justice and tries to argue that the current choice is fit even if it is not perfect.

This point can be substantiated by the long preamble of the Chinese Constitution both in its $19544^{55}$ and 1982 versions,${ }^{56}$ which contains a long historical review of the political struggles and experiments China experienced from the Opium War to the Revolution of 1911 and to the birth of the PRC in 1949. It doesn't provide principles

\footnotetext{
${ }^{46}$ Is Narendra Modi really an OBC? Rediff, May 10, 2014, http://www.rediff.com/news/column/ ls-election-sheela-says-is-narendra-modi-really-an-obc/20140510.htm

${ }^{47}$ Rahul Bedi, India set to elect president from lowest Dalit caste, Telegraph, July 17, 2017, http:// www.telegraph.co.uk/news/2017/07/17/india-set-elect-president-lowest-dalit-caste/.

${ }^{48}$ Unruhe, supra note 30.

${ }^{49}$ Pratap Bhanu Metha, The Burden of Democracy, Penguin Books, India 2003, p. 71.

${ }^{50}$ Metha, supra note 49, p. 74.

${ }^{51}$ Bardhan, supra note 9, p. 351.

${ }^{52}$ Amartya Sen, The Idea of Justice, Penguin Books, 2009, p. 5.

${ }^{53}$ Ibid.

${ }^{54}$ Sen, supra note 52 , p. 7.

${ }^{55}$ China Constitution 1954, http://e-chaupak.net/database/chicon/1954/1954bilingual.htm

${ }^{56}$ China Constitution 1982, http://www.npc.gov.cn/englishnpc/Constitution/node_2825.htm
} 
for an ideal society but instead argues why this is fit for China by comparison to other alternatives which have been tried.

Some Chinese scholars argue that the current Chinese system is of three integrations, that is, culturally Confucianism, politically socialism, and economically liberalism, which is the new consensus of reform sustained by the public reasoning. ${ }^{57}$ That is reflected in the constitutional governance of the party state, which places political power with the party and administrative power with the state. Following Confucianism and Leninism, power distribution in China is very centralized with the party state and parliamentary sovereignty, which would not be acceptable from the perspective of transcendental institutionalism. It also looks odd to combine fundamental rights with duties in the Chinese Constitution from the eyes of philosophers believing in liberal democracy. In terms of the strategy of enhancing justice or reducing injustice, the CPC identifies the improvement of material living conditions, including the right to a decent standard of living, health, education, housing, and so on as priorities, and places more focus on collective rights than individual rights, as it is more urgent to remove injustice. ${ }^{58}$

Compared to China, India more closely follows the model of transcendental institutionalism. The preamble of the Indian Constitution is very short, but lists four clear principles as the foundation for building the ideal society of justice, liberty, equality, and fraternity. ${ }^{59}$ India's Constitution borrowed the best systems of transcendental institutionalism, namely, the parliamentary government from the UK system, the judicial review and fundamental rights from the USA, and the federal structure from the Canadian Constitution. ${ }^{60}$ India's Constitution values civil and political rights more than economic and social rights, evidenced by placing the former as fundamental rights under judicial review in Part III and the latter as the guiding principles of state policy in Part IV. ${ }^{1}$ "For years, social rights, like the right to food, or the right to shelter, were considered subordinate to civil-political rights, like the right to free speech and/or the right to political participation." ${ }^{62}$ Unlike the Chinese way of integrating traditional philosophy with borrowed political philosophy from Western countries, Indian people have not tried to integrate them at the political level. ${ }^{63}$ For family and social life, Indians still follow traditional personal

${ }^{57}$ Zhou Lian, The Debate in Contemporary Chinese Political Thought, in Fred Dallmayr and Zhao Tingyang (ed.) Contemporary Chinese Political Thought: Debates and Perspectives, Knowledge World, New Delhi, 2013, pp. 34-36 Also from Gan Yang, The Road to China: Thirty Years and Sixty Years (in Chinese), Dushu 6, 2004, p. 5.

${ }^{58}$ Henri Feron, The Chinese Model of Human Rights, 3 China Legal Science (2015), p. 95.

${ }^{59}$ India Constitution (1950), http://lawmin.nic.in/olwing/coi/coi-english/Const.Pock\%202Pg. Rom8Fsss(3).pdf

${ }^{60}$ Krishan Keshav. Constitution Law-I, Delhi, Singhal Law Publication, 2016, p. 10.

${ }^{61}$ Gautam Bhatia, Directive Principles of State Policy, in Sujit Choudhry, Madhav Khosla, and Pratap Bhanu Mehta (ed.), The Oxford Handbook of the Indian Constitution, New York: Oxford University Press, 2016, p. 645.

${ }^{62}$ Madhav Khosla, The Indian Constitution, Oxford University Press, Sixth Impression, 2014, p. 126.

${ }^{63}$ Hanna Learner, The Indian Founding: A Comparative Perspective, in Choudhry et al. (ed.) The Oxford Handbook of the Indian Constitution, 2016, p. 61. 
law (religion or traditional philosophy), ${ }^{64}$ while in political life the people's passion is given to the ideal of liberal democracy.

To conclude, in China the dramatic class disruption prepared its people to embrace social arrangements such as access to primary education and basic health care in the pre-reform era, which further prepared for the capacities of economic and political participation. The centralized power and realization-focused comparison approach to justice give China flexibility to promote policy innovation for economic development as well as building infrastructure for economic facilities. The challenges in China are how to develop principle-based governance with logical reasoning to reduce the people's economic insecurity, which is critical for national innovation in the next step. In contrast, India has a very different path, with faith in the philosophy of evolutionary social change through ideal political arrangement. Constitutional democracy, including universal adult suffrage and judicial independence, has laid a good foundation for the rule of law as a principle of governance, whereas the function of the governance is limited by the big gap between ideal institutional arrangement and the huge social disparity.

\section{$4 \quad$ Power Distribution: Government Accountability vs. Policy Innovation}

One of the contributions of NIS is to bring the state back in exploring the catchingup process through innovation. How to identify the right intervention by the state? And how does the state implement the right intervention with the right timing and in the right way? The answers lie in the constitutional power distribution and its interaction with the social reality. In this part, I am going to introduce the difference in power distribution between India and China, including vertical power distribution of the central-local relationship, the horizontal power structure in terms of accountability and policy innovation, and the boundary between citizens' rights and state power. It is expected that the analysis will help provide some clues to understand the difference in the breadth of support for NIS in India and China.

\subsection{Vertical Power Distribution: Accountability vs. Local Innovation}

People usually define China as a centralized state, and India as a federal one. Upon closer examination, we may find the picture of the central-local relationship in both countries are much more complicated.

From the constitutional perspective, India is better framed as a quasi-federalist, or a federalist state with more central power. One of the critical perspectives is to look at its legislative power distribution. The seventh schedule of the Constitution

${ }^{64}$ Paras Diwan, Modern Hindu Law, Allahabad law Agency, 2017 Reprint, pp. 11-26. 
gives the union parliament residual power while the states have a fixed list of legislative powers. There is also a long list of powers jointly shared by the union and states. In addition, if the union government believes that some power is better exercised by them, they can pass a constitutional amendment to shift the power from the state to the union government. ${ }^{65}$ For example, primary education has been changed from the exclusive power of the states to joint power of the states and union government. ${ }^{66}$ "In situations where there is a union and state law conflict, Article 254 of the Indian Constitution prioritizes the former and renders the latter, to the extent of incompatibility or repugnancy, void." ${ }^{67}$ For executive power, there is a presidential rule under Article 356 of the Indian Constitution, according to which the president can declare failure of the constitutional machinery of a state, and the union government can exercise the executive power of the state during this emergency period. This power has been limited through judicial review in the case of S.R. Bommai after $1994 .{ }^{68}$

Even if the Constitution grants more power to the union government, it doesn't mean that the union government actually enjoys centralized and consolidated power over states in its daily function. In order to understand the functional practice, we also need to look at other factors, such as religious diversity, linguistic diversity, cultural diversity, multiparty politics, etc. India is very different from a traditional national state because it was built "in a social and political context in which the multinational dimension interacts with more linguistic and religious diversity. ${ }^{69}$ Before independence, there were more than 500 princely states, which maintained high-level autonomy through agreement with British India. After independence and partition, more than 400 of them were put under the modern state of India. India has more than 1000 parties at state, regional, and national levels which compete for power at different levels. These parties have diversified ideology such as Marxism, secularism with liberal democracy, Hindutva, support for low castes, etc. In many cases, the ruling parties at different levels are not the same, which makes the centralization of power very challenging. Even for building the streamlined tax system, the indirect tax reform such as the Goods and Services Tax reform just managed to pass on July 1, 2017 in India. ${ }^{70}$ At the grassroots level, in the 1990s, through the

\footnotetext{
${ }^{65}$ Khosla, Supra note 62, p. 47.

${ }^{66}$ Schedule 7, List III-Concurrent List, Entry 25 says "Education including technical education, medical education, and universities, subject to the provisions of entries 63,64,65 and 66 of List I; vocational and technical training of labor." Entry 25 of List III was introduced through the 42nd Amendment in 1976. From the Constitution of India Bare Act 2017, Universal law Publishing, p. 238.

${ }^{67}$ Khosla, supra note 62, p. 50.

${ }^{68}$ Khosla, supra note 62, pp. 64-65.

${ }^{69}$ Alfred Stepan, Juan J. Linz, and Yogendra Yadav, Crafting State-Nations: India and Other Multinational Democracies, John Hopkins University Press, 2011, pp. 39-40.

${ }^{70} \mathrm{VS}$ Krishnan, GST is one of the boldest reforms in post-Independence India, Indian Express, August 4, 2016, https://indianexpress.com/article/opinion/columns/gst-bill-passed-entry-52abolished-2952243/
} 
73rd and 74th amendments, three tiers of local government (panchayats) through direct elections were able to be established. ${ }^{71}$

In India, people value diversity more than scaling up exciting innovations. For example, the state of Kerala has been introduced by scholars and policymakers as a model of equitable development with high literacy and low disparity. However, many years later, India has only one "Kerala." The challenge involved in scaling up might lie in not only the willingness of the people but also its feasibility elsewhere in India.

However, in the Chinese context, Article 3 of the Constitution (1982) clearly sets forth the principle of democratic centralism for vertical power and horizontal power distribution. Meanwhile, China has created different levels of autonomy to deal with the return of previously colonized territorialities such as the high-level autonomous system named Special Administrative Region (SAR) for Macau and Hong Kong and to accommodate ethnic minorities with a middle-level autonomous system such as the autonomous administration system. The majority of provinces and municipalities are part of the centralized system, with a low level of political autonomy. In addition, China started experimenting with direct vote for village committees at the grassroots level starting from the late 1980s, which has become a nationally institutionalized system. ${ }^{72}$

It is further worth noting that Paragraph 4 of Article 3 of the Chinese Constitution (1982) sets out an interesting principle to deal with the relationship between central and local governments on policy experimentation and innovation, even for provinces with low levels of legal and political autonomy. It says "The division of functions and powers between the central and local State organs is guided by the principle of giving full scope to the initiative and enthusiasm of the local authorities under the unified leadership of the central authorities." 73 This means that even the provinces with low-level political autonomy still have big space for policy innovation. Scholars have framed this model as "fragmented authoritarianism" 74 or "market-preserving federalism." ${ }^{75}$ On the ground, the center gives local authorities space to test new ideas. If they fail, it is limited to the local.

\footnotetext{
${ }^{71}$ Dilip Mookherjee, "Governmental Accountability" in Niraja Gopal Jayal and Pratap Bhanu Mehta (ed.), The Oxford Companion to Politics in India, Oxford University Press India, 2010, p. 479.

${ }^{72}$ For more information, please refer to Chen Zhen, Dilemma, Balance and Remedy for Election at Village Committee from the Perspective of Self-governance at Grass-root Level, research for the 2016 National Civil Affaires Forum, http://mzzt.mca.gov.cn/article/2016mzlt/mzsyfztzflt/201610/20161000886907.shtml

${ }^{73}$ For the full text for Article 3, please refer to the link http://www.npc.gov.cn/englishnpc/ Constitution/2007-11/15/content_1372963.htm

${ }^{74}$ Haifeng Huang, Signal Left Turn to Right: Central Rhetoric and Local Reform in China, 66 Political Research Quarterly, No. 2 (June 2013), p. 294. Also from Kenneth G. Lieberthal and Michel Oksenberg, Policy Making in China: Leaders, Structures and Process, Princeton University Process, 1988.

${ }^{75}$ Huang, as supra note. Also from Cao Yuanzheng, Yingyi Qian, and Barry R. Weingast, From Federalism, Chinese Style of Privatization, Economics of Transition, No. 7, 1999, pp. 103-121.
} 
If it is successful then the central government can scale it up to the national level. In order to manage the pace, the rhetoric of the central government is usually conservative, but the local government can initiate unauthorized policy experiments based on their assessment of political risk. ${ }^{76}$ Scholars found that this experiment-based policymaking model provides a more powerful explanation than static factors for China's economic transformation. ${ }^{77}$

This mechanism of centralization of direction plus local autonomy has also evolved in terms of promoting geography of innovation. Before 2000, China has heavily used the top-down model of promoting geographical development, which is diffused in a hierarchical way. ${ }^{78}$ By comparing it with India, scholars have found that the agglomeration forces which lead to innovation have little spillover effect in China, since the innovation owes much to planned economy or aggressive policy intervention rather than being developed through natural social filters. ${ }^{79}$ For example, in the mid-2000s, the geography of patenting in China was much more concentrated, with $46 \%$ of patenting in Guangdong province, while in India it was more evenly distributed among the six cities of Bangalore, Chennai, Delhi, Hyderabad, Mumbai, and Pune. ${ }^{80}$

However, starting from 2010, there are some new signals toward the innovation direction. One is that the central direction toward local autonomy has been expanded toward both economic development and social development. The other is that the central government has shifted from directing local authorities' policy innovation to multi-stakeholder, multiform innovation. On September 29, 2010, in the 23rd Workshop of the Political Bureau of the Chinese Communist Party Central Committee, President Hu Jintao clearly set the tone that China should try the utmost to invigorate the innovation power of civil society. ${ }^{81}$ On March 5, 2011, in the Central Government Report to the National People's Congress (NPC), Premier Wen Jiabao mentioned in an unprecedented way that "China would mobilize and organize the public to join social management, and promote the positive role of civil society organizations and better governance." ${ }^{22}$ Almost from 2010, private tech business such as Sina, Baidu, Alibaba, and Tencent quickly grew. Cities started competition for high-tech companies. In 2017, driven by private business, the geographical distribution of patenting has been more expansive and evenly distributed

\footnotetext{
${ }^{76}$ Huang, supra note 74, p. 302.

${ }^{77}$ Sabastian Heilmann, From Local Experiments to National Policy, The Origins of China's Distinctive Policy Process, 59 China Journal, Jan. 2008, p. 29.

${ }^{78}$ Crescenzi et al., supra note 6, p. 25.

${ }^{79}$ Crescenzi et al., supra note 6, pp. 21-24.

${ }^{80}$ Ibid.

${ }^{81} \mathrm{Hu}$ Jintao Hosted the Twenty-Third Workshop for the Political Bureau of the Chinese Communist Party Central Committee, Xinhua News, Sep. 29, 2010, http://news.xinhuanet.com/politics/201009/29/c_13535934.htm

${ }^{82}$ Wen Jiabao: Strengthening the Capacity of Government in Social Management and Better Governance, Sina News, http://news.sina.com.cn/c/2011-03-05/104722057821.shtml
} 
compared to that of the mid-2000s: nearly all provinces patented, the top three changing to Guangdong, Zhejiang, and Jiangsu, with the percentage of Guangdong dropping from $46 \%$ to $24 \% .{ }^{83}$

\subsection{Horizontal Power Distribution: Accountability vs. Policy Innovation}

India developed the longest and most detailed constitution in the world through three years of deliberation, which establishes a functional separation of powers with formal political settings. Learning from reflection on Nazi Germany, India doesn't follow parliamentary sovereignty, but instead adopted the model of parliamentary government believing it to be effective and accountable. ${ }^{84}$ The Indian Constitution establishes universal adult suffrage. In addition, India learned from the USA to have an independent judiciary to check the tyranny of the majority. In India, among the three powers of executive, legislative, and judiciary, the judiciary is the most trusted one among the public. Through enforcing fundamental rights guaranteed by the Constitution in Part III and the judicial activism by developing a "basic structure doctrine," 85 India's Supreme Court is playing an omnipotent role in enforcing the Constitution. The Indian apex court even enjoys more power than its counterpart in the USA. ${ }^{86}$ For example, in India, Supreme Court and high court judges are appointed through a collegium, not subject to the real check of legislative and executive powers. ${ }^{87}$ Furthermore, "The [Supreme] Court devised ways of monitoring and disciplining the runaway exercises of constitution-amending powers, initially solely entrusted to Parliament and the Executive, via the invention of the doctrine of the basic structure and essential features of the Constitution." 88 The Indian Supreme Court is not confined to the conventional narratives of separation of powers but believes adjudicatory leadership or judicial supremacy. ${ }^{89}$ The adjudicatory leadership shapes India as a rule-based country, making governance function more like a forum of principle. The legal formalism and the check and balance in India lay a solid foundation for economic security, which is important for fostering entrepreneurship.

\footnotetext{
${ }^{83}$ Zhou Hui, Zhang Jianlin, 2017 China Patenting Report with Top Three of Guangdong, Zhejiang and Jiangsu, 21st Economic Report, April 27, 2018, http://finance.sina.com.cn/roll/2018-04-27/ doc-ifztkpin8971574.shtml

${ }^{84}$ Tom Ginsburg and Mila Versteeg, Why Do Countries Permit Constitutional Review, 30 Journal of Law, Economics and Organization (2014), p. 595.

${ }^{85}$ Manoj Mate, Two Paths to Judicial Power: The Basic Structure Doctrine and Public Interest Litigation in Comparative Perspective, 12 San Diego International Law Journal, Fall 2010.

${ }^{86}$ Upendra Baxi, Law, Politics, and Constitutional Hegemony: the Supreme Court, Jurisprudence and Demoprudence, Choudhry et al. (ed.) The Oxford Handbook of the Indian Constitution, Oxford University Press, 2016, New Delhi, p. 106.

${ }^{87}$ Mate, Supra note 85, pp. 204-206.

${ }^{88}$ Baxi, Supra note 86, p. 101.

${ }^{89}$ Baxi, Supra note 86, p. 106.
} 
However, short-run competitive populism in elections makes mobilization for votes more important than deliberation on how to reduce social injustice through collective efforts. For example, investment-related physical infrastructure and access to qualified education are usually not popular in election campaigns. ${ }^{90}$ Neither is it easy to carry out policy experimentation in India under legal formalism and competitive populism. ${ }^{91}$ In fact, the gap between elites' transcendental institutionalism and the social reality has also caused some odd phenomena, such as the persistent low ranking in contract enforcement for doing business in India by the World Bank. ${ }^{92}$ In contrast, Chinese contract enforcement has been among the top ten for many years. ${ }^{93}$ Equally unbelievable is the large number of delayed cases in India, 26.9 million in total as of May 19, 2018, including 2.25 million cases delayed over 10 years. ${ }^{94}$

India has a dual track of politicians and bureaucrats. In order to promote social equality, the Indian Constitution foresees seat reservation as the affirmative action through which scheduled tribes (ST), scheduled castes (SC), and other backward classes $(\mathrm{OBC})$ can be assigned reserved seats for elected positions and nonelected positions as bureaucrats in public sector and educational settings. The multiparty electoral democracy makes politicians very sensitive to constituents' concerns. But ethically, bureaucrats are expected to be apolitical. ${ }^{95}$ There is also constitutional protection for bureaucrats' job security. The apolitical ethics and the secured nature of bureaucratic jobs raise the question of how to transcend politician-based accountability to bureaucrat-based accountability.

The Chinese political system is an interesting combination of Confucianism and Leninism, a minority amidst the global prevalence of electoral democracy, ${ }^{96}$ in which governance is divided between the CPC with political power and the state with administrative power. ${ }^{97}$ Horizontal state power distribution follows the socalled democratic centralism or parliamentary sovereignty. The National Peoples' Congress has the supreme power to supervise all other powers including the

\footnotetext{
${ }^{90}$ Bardhan, supra note 9, p. 349.

${ }^{91}$ Ibid.

${ }^{92}$ N.L. Rajah, Courting the rankings, Hindu, Feb. 6, 2018, http://www.thehindu.com/opinion/ op-ed/courting-the-rankings/article22661678.ece

${ }^{93}$ On ease of doing business in China, see http://www.doingbusiness.org/data/exploretopics/ enforcing-contracts/china

${ }^{94}$ Data are from the daily updated NJDG database, http://164.100.78.168/njdg_public/main.php

${ }^{95}$ For more information about the ethics of bureaucrats in India, please refer to Arudra Burra, The Indian Civil Service and the Nationalist Movement: Neutrality, Politics and Continuity, 48 Commonwealth and Comparative Studies, No. 4, November 2010, pp. 404-432.

${ }^{96}$ Zheng Yong Nian, Chapter 2, The Chinese Communist Party as Organizational Emperor: Identity, Culture and Politics, in the book The Chinese Communist Party as Organizational Emperor: Culture, Reproduction and Transformation, Routledge Taylor \& Francis Group, Landon and New York, 2010, p.200.

${ }^{97}$ Larry Cata Backer, Party, People, Government, and State: on Constitutional Values and the Legitimacy of the Chinese Party-State Rule of Law System, 30 Boston University International Law Journal, 2012 Summer, p. 343.
} 
executive, judiciary, and military. The judiciary is a law-applying body, which has no power to check the legislative but has some power to check the executive through administrative litigations filed by citizens. The mechanism for the $\mathrm{CPC}$ as the ruling party to work with other democratic parties and stakeholders is called a "multi-party political consultation" system. Markets and civil society are slowly being released from the control of government after 1978.

Some scholars have summarized the Chinese political system as "democracy at the bottom and meritocracy at the top." 98 Above the town level, functionaries are selected among bureaucrats through supposed merit-based criteria, while at the grassroots level functionaries are elected through votes. That means bureaucrats and politicians are not separated clearly in the Chinese context but go through the same track. Compared to electoral democracy, functionaries selected through meritocracy will not have the issues of going through beginners' lessons or of tyranny of the majority, but have the challenge to build a sustainable meritocracy in a country with a huge population and diversity.

The different structure of the political system has a profound impact on government accountability and policy entrepreneurship. Both India and China claim to have a form of accountable government: India for having democratic institutional settings and China for identifying itself as serving the people's interests. However, government accountability functions in a very different way in each. In China, government accountability is mainly through internalization and self-reflection. Checks from external stakeholders such as other political parties, the judiciary, media, and civil society are very weak. The CPC, as the only ruling party since the establishment of the PRC, has tried to keep legitimacy and competency to rule the country by frequent self-disciplining and absorptive adaption. In turn, the CPC tries to internalize this reflection on their members to align personal interest with party interest and public interest. The CPC's accountability to the people is more outcome-based than procedure- or participation-based. In India, government accountability is mainly through external channels such as opposition parties, judiciary, media, and civil society, which are effective in checking politicians but may be less effective in checking bureaucrats.

\subsection{Constitutional Enforcement: Citizens' Rights vs. State Power}

In addition to allocating power vertically and horizontally for the function of the state, it is also important to look at how the constitution enforces citizens' rights. The Indian Constitution and Chinese Constitution both enumerate a long list of

\footnotetext{
${ }^{98}$ Daniel Bell, extracts from Chapter 4, The China Model: Political Meritocracy and The Limits of Democracy, Princeton University Press, 2015 p. 168.
} 
rights including civil and political rights and economic, social, and cultural rights for their citizens. Whereas most of the rights are similar in wording, there are some evident differences in terms of their enforcement mechanism and relationship with duties.

India's Constitution differentiates rights into two groups based on the enforcement mechanism. It places most of the civil and political rights under fundamental rights in Part III with the right to constitutional remedies through the Supreme Court while placing most economic, social, and cultural rights under Part IV "Directive Principles of State Policy." ${ }^{99}$ Some scholars have even criticized that the "Constitution incorporated civil-political rights with great gusto but stood silent on social rights." ${ }^{100}$ Some rights such as access to education for children at the ages of 6-14 have become a fundamental right through judicial activism. Through expansive judiciary interpretation of the "right to life" under Article 21, more and more economic and social rights such as the right to clean air, right to health, etc. are being recognized. ${ }^{101}$ India's Constitution is very right-based. For example, in order to improve the access to primary education, the Supreme Court of India has made access to education for school children (6-14 years) a fundamental right first. Parliament has also passed the Right to Education Act to endorse this right through legislative power. Even for compulsory education, the duty is for the state to provide education, while parents and school children have only the right but no duty to receive education.

In China, Chapter 2 of the Constitution concerns "fundamental rights and duties." It does not differentiate civil and political rights from economic, social, and cultural rights in terms of enforcement. The Constitution is enforced by the National People's Congress (NPC) and its Standing Committee (NPCSC). Article 62 prescribes that the NPC shall "supervise the enforcement of the Constitution." Article 67 empowers the NPCSC to "interpret the Constitution and supervise its enforcement." Although the judiciary cannot check the legislature under the parliamentary sovereignty, the Supreme People's Court (SPC) has experimented to make some constitutional rights justiciable, such as the right to education in the Qi Yuling case in 2001. ${ }^{102}$ However, the SPC repealed it later in 2009 for being controversial. ${ }^{103}$ In addition, the enforcement of constitutional rights in China is more toward collectivism and always with an eye on duty. In Chapter 2 of the Chinese Constitution, on top of the general

\footnotetext{
${ }^{99}$ Bhatia, supra note 61, p. 645.

${ }^{100}$ Khosla, supra note 62, p. 126.

${ }^{101}$ Vidhan Maheshwari, Article 21 of The Constitution of India-The Expanding Horizons, http:// www.legalserviceindia.com/articles/art222.htm

${ }^{102}$ Tong Zhiwei, A Comment on the Rise and Fall of the Supreme People's Court's Reply to $Q i$ Yuling Case, 43 Suffolk U. L. Review (2010), pp. 669-680.

${ }^{103}$ Keith Hand, Resolving Constitutional Disputes in Contemporary China, 7 East Asia Law Review, 2011, pp. 112-115, and 106-112.
} 
fundamental rights, two specific rights, namely, the right to education ${ }^{104}$ and right to work, ${ }^{105}$ are closely followed by duties.

While India is more rule-based China is more policy-oriented, such as experimentation-based policymaking ${ }^{106}$ with the "focus on finding innovative policy instruments rather than defining policy objectives," 107 especially after the era of reform and opening up era. In China, law is very general and leaves broad of leeway to policymakers, where legal issues are easily taken as political ones decided by the CPC. The governance function in China is more like a forum of policy, where in many circumstances experimentalism and policy orientation create space for entrepreneurship, such as the special economic zones in the 1980s, and recent pilot free trade zones. ${ }^{108}$ However, low priority for the rule of law also creates economic insecurity for the middle-class and business owners. The limited capacity in dealing with conflicts and diversities causes a law-stability paradox in legal reform and social transformation. ${ }^{109}$ " $[\mathrm{D}]$ ecentralization of power combined with central control over personnel and promotion plays in Chinese governance" 110 which enables China to "have more decisive policy initiative and execution than in India." 111 But "China is still far from establishing a comprehensive rule-based system and institutionalizing a credible set of checks and balances," 112 which will lead to "low capacity for conflict management [and] make it more brittle in the face of a crisis than the messy-looking system in India." 113

India's system has "more institutionalized outlets," which enables the enforcement of fundamental rights against government through an independent judiciary. However, its inability to deliver social service and take collective action despite populist hindrance cannot be overcome in a short period. ${ }^{114}$ "[The] over-politicized

\footnotetext{
${ }^{104}$ Article 46 provides that "Citizens of the People's Republic of China have the duty as well as the right to receive education," http://www.npc.gov.cn/englishnpc/Constitution/2007-11/09/content_ 1372846.htm

${ }^{105}$ Article 42 provides that "Citizens of the People's Republic of China have the right as well as the duty to work" (http://www.npc.gov.cn/englishnpc/Constitution/2007-11/09/content_1372846. $\mathrm{htm})$.

${ }^{106}$ Sebastian Heilmann, From Local Experimentation to National Policy : The Origins of China's Distinctive Policy Process, The China Journal No. 59, Jan. 2008, pp.1-30.

${ }^{107}$ Heilmann, p. 3.

${ }^{108}$ Such as the Pilot Free Trade Zone in Shanghai and the Hainan Pilot Free Trade Zone. For more information, please refer to http://en.china-shftz.gov.cn/ and Xinhua News report, http://www.xinhuanet.com/english/2018-04/13/c_137109244.htm

${ }^{109}$ Benjamin Liebman, "Legal Reform: China's Law-Stability Paradox,” Dadlus, Spring 2014, Vol. 143, No. 2, pp. 96-109 (2014), Online access http://www.mitpressjournals.org/doi/abs/10.1162/ DAED_a_00275\#.U1B7ZldWiO8, p. 96.

${ }^{110}$ Bardhan, supra note 9, p. 356.

${ }^{111}$ Bardhan, supra note 9, p. 353.

${ }^{112}$ Bardhan, supra note 9, p. 356.

${ }^{113}$ Bardhan, supra note 9, p. 357.

${ }^{114} \mathrm{Ibid}$.
} 
administration and decision-making processes, and its clogged courts and corrupt police and patronage politics that make a mockery of the rule of law for the common people all will continue to hobble the process of economic growth and alleviation of its still massive poverty." 115

\section{The Impact of Constitutional Governance on Economic Development Path and Innovation Strategy}

In this part, the impact of constitutional governance on economic development path and case studies of innovation capacities in India and China will be discussed.

\subsection{Impact on Economic Development Path}

Both China and India have regarded the centralized planned economy of the former Soviet Union as their role model for economic development from the late 1940s. China has tried to combine the party state with a planned economy and most unfortunately learned tragic lessons when millions of people starved to death. From 1978 onward, China started its groundbreaking economic reform, which combined the party state with a market economy. India has tried to combine democracy and a planned economy. The logic behind this is that India needs political freedom to break the societal inequality and believes that a centralized planned economy has helped boost economic development for its starving people by the millions. ${ }^{116}$ The end of the emergency period in 1976-1977 ${ }^{117}$ led to multiple parties competing for power in India. However, India still followed the planned economy together with multiparty elections until 1991. Even today, the role of the state in India's market economy continues to be very distinctive, different from the ones in liberal democracies or those in China and other East Asian countries.

In theory, there are different frameworks to understand the developmental stages of innovation. Some conceptualize a three-stage framework, namely, the stage of

\footnotetext{
${ }^{115}$ Ibid.

${ }^{116}$ Viswanathaiah, supra note 28, p. 94.

${ }^{117}$ According to Article 352 of the Indian Constitution, the Indian president has the power to announce that the country is in a state of internal emergency. During the emergency, fundamental rights shall be suspended. When Indira Gandhi served as prime minister, she felt the threat of internal disturbance and imposed emergency on the whole country, which was conducted through President Fakhruddin Ali Ahmed. The emergency period started from June 26, 1975, and lasted for 21 months. During the period, all fundamental rights of citizens were suspended. This was also called the darkest period of Indian democracy. For more information, please refer to India Emergency Era, The Times of India, June 25, 2015, https://timesofindia.indiatimes.com/india/ indian-emergency-era/photostory/47812701.cms. Also see Amrith Lal, 40 years on, those 21 Months of Emergency, The Indian Express, July 20, 2015, https://indianexpress.com/article/ explained/40-years-on-those-21-months-of-emergency/
} 
individual entrepreneurship (Shumpeter Mark I), ${ }^{118}$ the stage of big corporations as the main driver of innovation and economic growth (Mark II), and the stage where "a broader set of actors and institutions [shape] the innovation process" (Mark III). ${ }^{119}$ Some others divide economic development into a factor-driven stage, efficiency-driven stage and innovation-driven stage, and further distinguish necessity entrepreneurship from opportunity entrepreneurship, and also test their respective impact on economic development. ${ }^{120}$ Necessity entrepreneurship means there is very limited access to wage jobs, and entrepreneurship is the way to make a living. "The relationship between necessity entrepreneurship and economic development is usually negative in low-income countries, while the relationship in high-income countries is most likely positive." ${ }^{121}$ Economic studies have also shown that "opportunity entrepreneurship has a big impact on economic development, whereas necessity entrepreneurship has no effect." 122

China's economic model has been framed by many scholars as state capitalism, which is the combination of a market economy and strong government. The state has a strong hand in directing economic development and also heavily intervenes in markets and other issues related to NIS such as education, and geography of innovation. The three stages experienced by China are very much in line with the Western model of development, which is from factor driven, to efficiency driven and then to innovation driven.

In order to move to the efficiency-driven stage, "countries must increase their production efficiency and educate the workforce to be able to adapt in the subsequent technological development stage," 123 which is "marked by decreasing selfemployment." 124 To move to the third stage, the economy will "shift from large corporations to entrepreneurial firms, marked by decreasing the share of manufacturing in the economy." 125

\footnotetext{
${ }^{118}$ Scholarship attributes the theory development of entrepreneurship to the economist Joseph Schumpeter. His two theories on entrepreneurship sometimes were called Mark I and Mark II. In Mark I, "Schumpeter argued that the innovation and technological change of a nation come from the entrepreneurs, or wild spirits." In Mark II, "he asserted that the actors that drive innovation and the economy are big companies which have the resources and capital to invest in research and development. Both arguments might be complementary today." Introduction to Joseph Schumpeter, https://www.saylor.org/site/wp-content/uploads/2011/03/JosephSchumpeter.pdf

${ }^{119}$ Lundvall, supra note 1, p. 7. (Mark III was not from Schumpeter, but it was used to show the theoretical trend of entrepreneurship developed by Schumpeter.)

${ }^{120}$ Zoltan J. Acs, Sameeksha Desai, and Jolanda Hessels, Entrepreneurship, economic development and institutions, 31 Small Business Economics, No. 3, Special Issue: Entrepreneurship, economic development, and institutions, Oct. 2008, pp. 219-234. (Opportunity entrepreneurship refers to "starting a business to exploit a perceived business opportunity," while necessity entrepreneurship refers to "starting a business because you were pushed into it" (p. 222).)
}

${ }^{121}$ Acs et al., supra note 121, p. 222.

${ }^{122}$ Acs et al., supra note, 121, p. 219. Also from Zoltan J. Acs and A. Varga, Enterprises, Agglomeration, and Technology Change, 24 Small Business Economics, No. 3, 2005, pp. 323-334.

${ }^{123}$ Acs et al., supra note 121, p. 221.

${ }^{124}$ Ibid.

${ }^{125}$ Ibid. 
China and India have experimented with different paths of economic development. "China has experienced explosive growth in its industrial sector, whereas India's growth has been fueled by the expansion of service-producing industries." 26 One of the consequences from lack of large-scale manufacturing in India is that India's economic development path is the distinctive role of the service sector, which has resulted in big employment in the informal sector. ${ }^{127}$ For example, by 2008-2009, in India, the service sector contributed 57\% of GDP, agriculture 17\% (55\% in $1950-1951^{128}$ ), and the manufacturing sector the remaining $26 \% .^{129}$ Data show that India has been on a fast track of moving people out of low-productivity agriculture into the manufacturing and service sectors. ${ }^{130}$ However, workers released from agriculture have not been employed in large-scale manufacturing or the formal service sector but are mostly in the self-employment sector. In India, even during the period of the heavily planned economy, "The growth of entrepreneurship was autonomous, brought about without state initiative." 131 It seems that even today, India is still dominated by individual entrepreneurship, which is more necessity entrepreneurship than opportunity entrepreneurship.

Why did India and China take different economic paths? From the perspective of constitutional governance, many factors can be brought into the discussion.

First is how to deal with cost factors such as land, labor, and tax which are critical for attracting foreign direct investment (FDI) at the initial development stage. Let's take the example of land. In India, land reform has been critical for the social and economic liberation of farmers in rural areas. Nehru has fought several battles over land reform with the judiciary, who as gatekeeper for the constitutional democracy has substantially checked the ambition of Nehru. ${ }^{132}$ The land reform was only half implemented, which created barriers for developing a large-scale manufacturing sector in terms of land supply and stable labor supply. In contrast, in China, through bloody revolution and the Cultural Revolution, farmers were completely "liberated." Through several steps, land ownership is finally in the form of state ownership in urban areas and collective ownership in rural ones, which made access to land much easier.

Second, NIS scholars believe that "a key to transform technical innovation into economic results is training and organizational change." ${ }^{133}$ Lack of educated labor

\footnotetext{
${ }^{126}$ Barry Bosworth and Susan M. Collins, Accounting for Growth: Comparing China and India, NBER Working Paper Series, Working Paper 12,943, February 2007, http://www.nber.org/papers/ w12943.pdf, p. 2.

${ }^{127}$ Barry Eichengreen and Poonam Gupta, The Service Sector as Indian's Road to Economic Growth, NBER Working Paper Series, Feb. 2011, available at: http://www.nber.org/papers/w16757. pdf, p. 1.

${ }^{128}$ Eichengreen and Gupta, supra note 126, p. 3.

${ }^{129}$ Ibid.

${ }^{130}$ Ibid.

${ }^{131}$ Medhora, supra note 31, p. 580.

${ }^{132}$ Mate, supra note 85 , pp. 179-181.

${ }^{133}$ Lundvall supra note 1, p. 8.
} 
is challenging for developing large-scale employment in manufacturing and also undermines the transformation of technical innovation into economic results in India. Primary education was initially within the power of state government, whereas higher education was in the hands of the union government. Nehru's ambition for developing science and technology through developing advanced higher education at the union level neglected primary education at the state level, which makes access to primary education very problematic in India even today, with nearly one third of adults illiterate, while China prepares educated labor for manufacturing through more aggressive compulsory education policy.

Third, labor mobility is important for employment and the learning capacity of ordinary citizens. Even if the social equality in India is slowly developing, still largely influenced by religion and traditional culture. Indian family life is under the personal law, which is mainly based on religion, such as Hindu Law, Muslim Law, Christian Law, Jewish Law, and Parsi Law. Therefore, marriage, adoption, and inheritance and related social life are subject to religion and traditional culture. That means that, although the Constitution tries to remove the barrier of social inequality, the personal law allows and even strengthens the role of religion and caste culture to differentiate personal status. This permeation of personal law in daily life undermines the constitutional ambition to remove caste-based discrimination and thus hinders labor mobility for large-scale employment and the learning capacity of ordinary citizens.

Last, access to global markets is also influenced by a country's constitutional governance. As a comparatively mature and liberal democracy with less aggressive government, India gets more trust from developed countries than China can get, which makes India's access to global markets much easier, especially in providing service. For example, lack of government censorship and more freedom of technical connection with the world could be the reasons that India is more competitive in software service, which better connects India with the global market. China, however, will continue to face the dilemma of promoting globalization while restricting the information connection with the world. In addition, the low level of institutionalization of checks and balances in China will cast doubt on and cause uncertainty for its political establishment and its capacity in dealing with unexpected dramatic social changes, which is negative for sustainable innovation in the globalized context.

\subsection{Case Study on ICT of the Impact on Innovation Strategy}

There are some similarities between India and China in their catching-up process. "The large and growing internal market and the enormous capital accumulation resulting from long periods of fast growth give government and firms exceptional power to purchase, negotiate and trade...."134 Also, India and China share some similarities for innovation strategy, such as embedding themselves in the "global

${ }^{134}$ Altenburg et al., supra note 4, p. 328. 
value chain" and connecting with "global professional work." ${ }^{135}$ However, they vary significantly in terms of how to use their bargaining power in the catching-up process. The innovation strategy in the information and communication technology (ICT) sector serves as an example for analysis.

ICT has been a hot topic for comparative studies of innovation in India and China. This sector involves some key stakeholders such as communication equipment manufacturers, service providers, and consumers. It also involves the standards setting of $3 \mathrm{G}, 4 \mathrm{G}$, and $5 \mathrm{G}$. The ICT sector started developing in the early 1990s in India and China, right after economic liberalization. ${ }^{136}$ Despite similar opportunities and challenges of developing $3 \mathrm{G}$ in India and China, they took very different strategies for developing the $3 \mathrm{G}$ standard, "with China heavily investing in a homegrown standard TD-SCDMA and India preferring the international standard." 137 The homegrown standard in China was not initiated by the government, but was a joint initiative by the Chinese Academy of Telecommunication Technology (with funding from government) and a US firm named Cwill in 1995, which was later joined by Siemens. ${ }^{138}$ From 2003 onward, the Chinese government realized its strategic importance for national innovation capacity and started investing in its commercialization by providing research subsidies and loans and also asking the state-run mobile service provider China Mobile to adopt the homegrown standard. ${ }^{139}$ A similar strategy has been used for the upgrading of $3 \mathrm{G}$ to $4 \mathrm{G}$ (TD-LTE) ${ }^{140}$ and now for standard setting of 5G (Polar). ${ }^{141}$ In addition, domestic equipment manufacturers such as Huawei and Datang benefited greatly from the homegrown standard setting. Some even believes that "The TD-SCDMA is not a standard policy, but a subsidy policy to nurture domestic companies into

\footnotetext{
${ }^{135} \mathrm{Ibid}$.

${ }^{136}$ China started the Open up and Reform policy from 1978. However, it was at the 14th Congress of CPC in 1992 that the goal of economic reform was formally set to build a market economy with socialist character. Due to its debt crisis, India started the economic reform mainly by ending license permits and decreasing government intervention in business from 1991, pushed by Finance Minister Manmohan Singh. See Hu Jiayong, The Development and Framework of Market Economy with Socialist Character in China, People. Com, Sep. 2, 2016, http://theory.people.com. cn/n1/2016/0902/c148980-28685995.html, and Aprameya Rao and Kishor Kadam, 25 Years of Liberalization: A Glimpse of India's Growth in 14 Charts, The Firstpost, July 7, 2016, https:// www.firstpost.com/business/25-years-of-liberalisation-a-glimpse-of-indias-growth-in14-charts-2877654.html

${ }^{137}$ Chun Liu and Krishna Jayakar, Globalization, Indigenous Innovation and National Strategy: Comparing China and India's Wireless Standardization, paper presented at TRIC 2013, pp. 17-18.

${ }^{138}$ Liu and Jayakar, supra note 138, p. 6.

${ }^{139}$ Liu and Jayakar, supra note 138, pp. 6-8.

${ }^{140}$ Liu and Jayakar, supra note 138, p. 9.

${ }^{141}$ Xiang Ligang, What 5G Means to China (in Chinese), China Economic Weekly No. 20, 2018, reposted by Ifeng Finance on May 22, 2018 at http://finance.ifeng.com/a/20180522/16301597_0. shtml
} 
international champions." 142 By 2018, Huawei became the no. 1 communication equipment manufacturer in the world. ${ }^{143}$

In contrast, India adopted the international standard, which is a reasonable decision from the perspective of service providers and consumers. However, it doesn't mean India has not thought of having its own homegrown technology. In a comparative study of the telecom industry in India and China in 2005, Sunil Mani attributed the lower development of ICT in India to the fact that India followed a rigid policy of domestic development of technology such as "establishing a stand-alone public laboratory which was charged with the responsibility of developing a family of digital switching equipment and then transferring this generated technology to domestic public and private sector telecom equipment manufacturers," 144 while China went from the stage of depending on multinational enterprises' technology to encouraging in-house $R \& D$ in state-owned enterprises and private firms for technology competition. ${ }^{145}$

Later research by Chun Liu and Krishna Jayakar explored the reasons of no homegrown standard in India in greater depth. First, it was very challenging to coordinate the commercialization of the less favorable homegrown standard in India. After the economic liberalization, the two remaining state-owned companies were not competitive, while private service providers were diversified and too competitive. ${ }^{146}$ In many areas, there were $11-16$ service operators competing for service. ${ }^{147}$ In China, the reform of state-owned service providers has been through managed competition, with a smaller number, three to five, of state-owned companies. This has made commercialization much easier. Second, India didn't have big equipment manufacturers to take advantage of the homegrown standard in the early 2000s. ${ }^{148}$ Finally, Indians generally don't trust government. The $2 \mathrm{G}$ spectrum license scandal in $2009^{149}$ drew more public suspicion toward government in telecommunication management. ${ }^{150}$ This has made the adventurous option of developing homegrown standards even more impossible.

\footnotetext{
${ }^{142}$ Liu and Jayakar, supra note 138, p. 17.

${ }^{143}$ Xiang, supra note 142.

${ }^{144}$ Sunil Mani, The Dragon v. the Elephant, Comparative Analysis of Innovation Capacity in the Telecom Industry of China and India, 40 Economic and Political Weekly, Vol. 40, No. 39, Sep. 24-30, 2005, pp. 4271-4283, p. 4281.

${ }^{145} \mathrm{Ibid}$.

${ }^{146}$ Liu and Jayakar, supra note 138, pp. 15-16.

${ }^{147}$ Liu and Jayakar, supra note 138, p. 16.

${ }^{148}$ Liu and Jayakar, supra note 138, pp. 14-15.

149 "The $2 \mathrm{G}$ spectrum scam involved politicians and government officials in India illegally undercharging mobile telephony companies for frequency allocation licenses, which they would then use to create $2 \mathrm{G}$ subscriptions for cell phones." For more information, please refer to What is the 2G spectrum scam? India Today, October 19, 2012, https://www.indiatoday.in/india/story/ what-is-the-2g-scam-all-about-102224-2012-10-19.

${ }^{150}$ Liu and Jayakar, supra note 138, p. 11.
} 
This example demonstrates that contextualized factors, including "problem identification, policy objective, implementation philosophies, points of intervention, policy for data and informational needs, political and institutional contexts, key events and public policies," ${ }^{151}$ will decide different strategies for China and India. Specific to this case, the reform of state-owned enterprises, the R\&D strategy, the role of government, and the interaction with the global value chain became deciding factors for strategic differences in the ICT innovation strategy in India and China.

\section{Conclusion}

Innovation is not just about technical and organizational change at the firm level but also about the socially and spatially interactive learning process between firms and the wider institutional support. As Lundvall emphasized in his research, "shared value" and the "power structure" should be factored into in research on NIS, since they constitute important barriers to competence building for innovation in developing countries. This chapter has tried to explore these factors in a non-quantified but analytical way.

Broadly speaking, following its non-violent strategy of civil disobedience for the independence movement, the social revolution after independence in India is also through non-violent means, mainly through universal adult suffrage. In pursuing social justice, India adheres to the idea of transcendental institutionalism and has institutionalized a credible set of checks and balances through electoral democracy plus independent judicial review.

China has followed Leninism, with violent revolution for social emancipation. The radical social transformation has helped China build a wider setting for innovation such as strong awareness of social equality, access to health and education, and rapid development of physical infrastructure. For the idea of justice, China is more in line with the idea of realization-based comparison. Its centralized power and policy-oriented administration make government responsive and flexible in promoting innovation, but at the costs of insecurity and uncertainty caused by the low level of rule-based institutionalization.

The design of vertical and horizontal power distribution as well as the boundary setting between state and citizens in India and China is very much in line with their respective political philosophies. In India, the horizontal power with strong checks helps it to build a rule-based governance. Elections also serve as the means to hold politicians accountable and sanction them when necessary. However, the dual tracks of politicians and bureaucrats, reservations and quotas as fundamental rights in education and employment, and the disparity among institutional settings and social

\footnotetext{
${ }^{151}$ Daniel A Mazmanian, Michael E Kraft, The Three Epochs of Environmental Movement, in Daniel A. Mazmanian and Michael E. Kraft (ed.) Toward Sustainable Communities: Transition and Transformations in Environmental Policy, Published on University Press Scholarship Online, 2009, DOI:https://doi.org/10.7551/mitpress/9780262134927.001.0001, p. 12.
} 
disparity make government accountability and policy entrepreneurship problematic. The quasi-federal system gives the union government comprehensive power to coordinate with states or even to dominate states. However, the diversity of languages, political parties, and cultures as well as the freedom of religion in India limits the chances of scaling up entrepreneurial policies.

China uses the decentralization of power for local entrepreneurship and the central control of personnel promotion for the constitutional principle of democratic centralism. The state plays a more aggressive role in resource allocation and mobilization for innovation. In the geography of innovation, China has a top-down development model, creating a hierarchy of subnational innovation, thereby limiting the spillover effect. Fortunately, in the last several years, the boom of private businesses has helped make geographical distribution of innovation more equitable.

\section{References}

Acs, Z. J., \& Varga, A. (2005). Enterprises, agglomeration and technology change. Small Business Economics, 24(3), 323-334.

Acs, Z. J., Desai, S., \& Hessels, J. (2008, October). Entrepreneurship, economic development and institutions. Small Business Economics, 31(3, Special Issue), 219-234.

Alfred, S., Linz, J. J., \& Yadav, Y. (2011). Crafting State-Nations: India and other multinational democracies (pp. 39-40). Baltimore: John Hopkins University Press.

Altenburg, T., Schmitz, H., \& Stamm, A. (2008). Breakthrough? China's and India's transition from production to innovation. World Development, 36(2), 325-344.

Amartya, S. (1999). Development as freedom (pp. 39-42). Oxford: Oxford University Press.

Amartya, S. (2009). The idea of justice (pp. 5-7). London: Penguin Books.

Austin, G. (2009). The Indian constitution: Cornerstone of a nation (p. 58). New Delhi: Oxford University Press.

Backer, L. C. (2012, Summer). Party, people, government and state: On constitutional values and the legitimacy of the Chinese party-state rule of law system. Boston University International Law Journal, 30, 331-408.

Bardhan, P. (2009, May). Indian and China: Governance issues and development. Journal of Asian Studies, 68(2), 347-357.

Baxi, U. (2016). Law, politics, and constitutional hegemony: The supreme court, jurisprudence and demosprudence. In S. Choudhry et al. (Eds.), The Oxford handbook of the Indian constitution (pp. 94-109). New Delhi: Oxford University Press.

Bedi, R. (2017, July 17). India set to elect president from lowest Dalit caste. Telegraph. http:// www.telegraph.co.uk/news/2017/07/17/india-set-elect-president-lowest-dalit-caste/

Bell, D. (2015). The China model: Political meritocracy and the limits of democracy. Princeton: Princeton University Press, Extracts from Chapter 4, p. 168.

Bosworth, B., \& Collins, S. M. (2007, February). Accounting for growth: Comparing China and India (NBER Working Paper Series, Working Paper 12943), p. 2. http://www.nber.org/papers/ w12943.pdf

Burra, A. (2010, November). The Indian civil service and the nationalist movement: Neutrality, politics and continuity. Commonwealth and Comparative Studies, 48(4), 404-432. 
Crescenzi, R., Rodriguez-Pose, A., \& Storper, M. (2012). The territorial dynamics of innovation in China and India. Journal of Economic Geography, 12(5), 1055-1085.

Department of School Education \& Literacy. (2016). Ministry of Human Resources Development (MHRD), Education Statistics at a Glance, p. A1. http://mhrd.gov.in/sites/upload_files/mhrd/ files/statistics/ESG2016_0.pdf

Dilemma, C. Z. (2016). Balance and remedy for election at village committee from the perspective of self-governance at grass-root level, research for the 2016 National Civil Affairs Forum. http://mzzt.mca.gov.cn/article/2016mzlt/mzsyfztzflt/201610/20161000886907.shtml

Diwan, P. (2017). Modern Hindu law. Allahabad law Agency, 2017 Reprint, pp. 11-26.

Eichengreen, B, \& Gupta, P. (2011, February). The service sector as Indian's road to economic growth (NBER Working Paper Series), p. 1. Available at: http://www.nber.org/papers/w16757. pdf

Fagerberg, J., Fosaas, M., Bell, M., \& Martin, B. (2010). Chris Freeman's contribution to innovation studies (EXPLORE Workshop), pp. 4-5. http://www.janfagerberg.org/wp-content/ uploads/2013/08/Chris-Freeman\%E2\%80\%99s-contribution-to-innovation-studies-1.pdf

Fan, P. (2008). Innovation capacity and economic development: China and India. Research Paper, UNU-WIDER, United Nations University (UNU), No. 2008/31, ISBN 978-92-9230-077-7.

Feron, H. (2015). The Chinese model of human rights. China Legal Science, 3(3), 95.

Gautam Bhatia, Directive principles of state policy, in The Oxford handbook of the Indian constitution Sujit Choudhry, Madhav Khosla and Pratap Bhanu Mehta, New York: Oxford University Press, 2016, pp. 644-661.

Ginsburg, T., \& Versteeg, M. (2014). Why do countries permit constitutional review? Journal of Law, Economics and Organization, 30, 587-639.

Hanumantha Rao, C. H. 2011, April 16-22). India and China: A comparison of the role of Sociopolitical factors in inclusive growth. Economic and Political Weekly, 46, 16: 24-28.

Hui, Z., \& Jianlin, Z. (2017). China Patenting report with top three of Guangdong, Zhejiang and Jiangsu, 21st Economic Report, April 27, 2018. http://finance.sina.com.cn/roll/2018-04-27/ doc-ifztkpin8971574.shtml

India Today. What is the $2 \mathrm{G}$ spectrum scam? October 19, 2012, https://www.indiatoday.in/india/ story/what-is-the-2g-scam-all-about-102224-2012-10-19

Introduction to Joseph Schumpeter. https://www.saylor.org/site/wp-content/uploads/2011/03/ JosephSchumpeter.pdf.

Ishii, K. (2001, September). The socioeconomic thoughts of mahatma Gandhi: As an origin of alternative development. Review of Social Economy, LIX(3), 301.

Jiancheng, X. U., Hongxiang, M. A. O., \&Yi, F. (2010, June 12). Contextualized analysis on Chinese human resources (in Chinese). Shanghai Institute of Education Studies. http://www. cnsaes.org/homepage/Upfile/2010612/2010061205505377.pdf

Jiayong, H. (2016, September 2). The development and framework of market economy with socialist character in China. People.Com. http://theory.people.com.cn/n1/2016/0902/c14898028685995.html

Keshav, K. (2016). Constitution law-I (p. 10). Delhi: Singhal Law Publication.

Khosla, M. (2014). The Indian constitution (pp. 47-126). Oxford: Oxford University Press, Sixth Impression.

Krishnan, V. S. (2016, August 4). GST is one of the boldest reforms in post-Independence India. Indian Express. https://indianexpress.com/article/opinion/columns/gst-bill-passed-entry52-abolished-2952243/

Lal, A. (2015, July 20). 40 years on, those 21 months of Emergency. The Indian Express. https:// indianexpress.com/article/explained/40-years-on-those-21-months-of-emergency/ 
Learner, H. (2016). The Indian founding: A comparative perspective. In S. Choudhry et al. (Eds.), The Oxford handbook of the Indian constitution (pp. 55-70). Oxford: Oxford University Press.

Lian, Z. (2013). The debate in contemporary Chinese political thought. In F. Dallmayr \& Z. Tingyang (Eds.), Contemporary Chinese political thought: Debates and perspectives, knowledge world (pp. 34-36). New Delhi. Also from Gan Yang, The Road to China: Thirty years and sixty years (in Chinese), Dushu 6, 2004, p. 5.

Liebman, B. (2014). Legal reform: China's law-stability paradox. Dadlus, Spring, 143(2), 96-109, Online access http://www.mitpressjournals.org/doi/abs/10.1162/DAED_a_00275\#. U1B7ZldWiO8.

Liu, C., \& Jayakar, K. (2013). Globalization, indigenous innovation and national strategy: Comparing China and India's wireless standardization, paper presented at TRIC 2013.

Lundvall, B-A.. (2005, June 28-29). National innovation systems-Analytical concept and development tool, second version of the paper presented at the DRUID conference in Copenhagen. Available at: https://www.researchgate.net/publication/24081600_National_Innovation_ Systems-Analytical_Concept_and_Development_Tool

Maheshwari, V. Article 21 of the constitution of India - The expanding horizons. http://www. legalserviceindia.com/articles/art222.htm

Mani, S. (2005). The dragon v. the elephant, comparative analysis of innovation capacity in the telecom industry of China and India. Economic and Political Weekly, 40(39), 4271-4283.

Mate, M. (2010, Fall). Two paths to judicial power: The basic structure doctrine and public interest litigation in comparative perspective. San Diego International Law Journal, 12, 175-222.

Mazmanian, D. A., \& Kraft, M. E. (2009). The three epochs of environmental movement. In D. A. Mazmanian \& M. E. Kraft (Eds.), Toward sustainable communities: Transition and transformations in environmental policy (p. 12). Cambridge, MA/London: MIT Press. Published at University Press Scholarship Online, https://doi.org/10.7551/ mitpress/9780262134927.001.0001.

Medhora, P. B. (1965, December). Entrepreneurship in India. Political Science Quarterly, 80(4), $558-580$.

Metha, P. B. (2003). The burden of democracy (pp. 71-74). New Delhi/New York: Penguin Books, India.

Mookherjee, D. (2010). Governmental accountability. In N. G. Jayal \& P. B. Mehta (Eds.), The Oxford companion to politics in India (pp. 477-482). New Delhi: Oxford University Press India.

Rajah N. L. (2018, February 6). Courting the rankings. Hindu. http://www.thehindu.com/opinion/ op-ed/courting-the-rankings/article22661678.ece

Rao, A, \& Kadam, K. (2016, July 7). 25 years of liberalisation: A Glimpse of India's growth in 14 charts. The Firstpost. https://www.firstpost.com/business/25-years-of-liberalisation-a-glimpseof-indias-growth-in-14-charts-2877654.html.

Rediff. (2014, May 10). Is Narendra Modi really an OBC? http://www.rediff.com/news/column/ ls-election-sheela-says-is-narendra-modi-really-an-obc/20140510.htm

Rosenberg, N. (2004). Innovation and economic development. OECD, p. 1. https://www.oecd.org/ cfe/tourism/34267902.pdf

Sina News. Wen Jiabao: Strengthening the capacity of government in social management and better governance. http://news.sina.com.cn/c/2011-03-05/104722057821.shtml

Unruhe, J. (2010, July 20). Contrast India \& China: What a difference revolution makes! Jason Unruhe.Com. https://maoistrebelnews.com/2010/07/20/contrast-india-china-what-a-differencerevolution-makes/

Viswanathaiah, K. V. (1965). Jawaharlal Nehru's concept of democratic socialism. The Indian Journal of Political Science, 26(4), 91-99.

World Bank Group. Ease of doing business in China report. http://www.doingbusiness.org/data/ exploretopics/enforcing-contracts/china 
Xiang Ligang. What 5G means to China (in Chinese), China economic weekly No. 20 2018, reposted by Ifeng Finance on May 22, 2018 at http://finance.ifeng.com/a/20180522/16301597_0.shtml

Xinhua News. (2010, September 29). Hu Jintao hosted the twenty third workshop for the political Bureau of the Chinese Communist Party Central Committee. http://news.xinhuanet.com/ politics/2010-09/29/c_13535934.htm

Yongnian, Z. (2010). Chapter 2: On the Chinese Communist Party as organizational emperor: Identity, culture and politics. In The Chinese Communist Party as organizational emperor: Culture, reproduction and transformation (p. 200). London/New York: Routledge Taylor \& Francis Group.

Open Access This chapter is licensed under the terms of the Creative Commons Attribution 4.0 International License (http://creativecommons.org/licenses/by/4.0/), which permits use, sharing, adaptation, distribution and reproduction in any medium or format, as long as you give appropriate credit to the original author(s) and the source, provide a link to the Creative Commons license and indicate if changes were made.

The images or other third party material in this chapter are included in the chapter's Creative Commons license, unless indicated otherwise in a credit line to the material. If material is not included in the chapter's Creative Commons license and your intended use is not permitted by statutory regulation or exceeds the permitted use, you will need to obtain permission directly from the copyright holder.

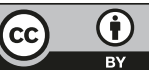

